\title{
A NEW METHOD FOR ESTABLISHING AND PROVING ACCURATE BOUNDS FOR THE WALLIS RATIO
}

\section{CRISTINEL MORTICI}

Abstract. The aim of this paper is to establish new inequalities about the Wallis ratio that improve the Gautschi-Kershaw results.

Mathematics subject classification (2010): 33B15, 41A10, 42A16.

Keywords and phrases: Wallis ratio, gamma function, approximations, inequalities.

\section{REFERENCES}

[1] H. AlzER, On some inequalities for the incomplete gamma function, Math. Comp., 66 (1997), 771778.

[2] H. AlzER, On some inequalities for the gamma and psi functions, Math. Comp., 66, 3 (1997), $373-$ 389.

[3] J. M. BORWEIN, AND O.-Y. CHAN, Uniform bounds for the complementary incomplete gamma function, Math. Inequal. Appl., 12, 1 (2009), 115-121.

[4] A. V. BoyD, Note on a paper by Uppuluri, Pacific J. Math., 22 (1967), 9-10.

[5] J. T. CHU, A modified Wallis product and some application, Amer. Math Monthly, 69 (1962), 402 404.

[6] N. Elezović, C. Giordano, And J. PeČArić, The best bounds in Gautschi's inequality, Math. Inequl. App., 3, 2 (2000), 239-252.

[7] N. Elezović, AND J. PeČArić, Differential and integral $f$-means and applications to digamma function, Math. Inequal. Appl., 3, 2 (2000), 189-196.

[8] G. M. Fintenholt, Course on differential and integral calculus, vol. 2, Moscow, 1969.

[9] W. GAUTSCHI, Inequalities for gamma and incomplete gamma function, J. Math. Phys., 39 (1959), $77-81$.

[10] J. GuRland, On Wallis' formula, Amer. Math. Monthly, 63 (1956), 643-645.

[11] D. K. KAZARINOFF, On Wallis' formula, Edindurgh Math. Notes, 40 (1956), 19-21.

[12] D. Kershaw, Some extentions of W. Gautschi's inequalities for the gamma function, Math. Comp., 41, 164 (1983), 607-611.

[13] S. Koumandos, Monotonicity of some functions involving the gamma and psi functions, Math. Comp., 77 (2008), 2261-2275.

[14] A.-J. LI, J. YUAN, AND C.-P. Chen, Monotonicity results for the polygamma functions, Math. Inequal. Appl., 11, 3 (2008), 307-316.

[15] D. S. MitRINOVIĆ, Elementary Inequalities, Gröningen, 1964.

[16] C. MorticI, Product approximations via asymptotic integration, Amer. Math. Monthly, 117, 5 (2010).

[17] C. MoRTICI, An ultimate extremely accurate formula for approximation of the factorial function, Arch. Math. (Basel), 93, 1 (2009), 37-45.

[18] C. MorTici, New approximations of the gamma function in terms of the digamma function, Appl. Math. Lett., 23, 3 (2010), 97-100.

[19] C. Mortici, New sharp bounds for gamma and digamma functions, An. Ştiinţ. Univ. A. I. Cuza Iaşi Ser. N. Matem., 562 (2010), in press.

[20] C. Mortici, Complete monotonic functions associated with gamma function and applications, Carpathian J. Math., 25, 3 (2009), 186-191. 
[21] C. MorTiCI, Optimizing the rate of convergence in some new classes of sequences convergent to Euler's constant, Anal. Appl. (Singap.), 8, 1 (2010), 99-107.

[22] C. MoRTICI, Improved convergence towards the generalized Euler-Mascheroni constant, Appl. Math. Comput., 215 (2010), 3443-3448.

[23] C. MoRTiCi, Best estimates of the generalized Stirling formula, Appl. Math. Comput., 215, 11 (2010), 4044-4048.

[24] P. Natalini, AND B. Palumbo, Inequalities for the incomplete gamma function, Math. Inequal. Appl., 3, 1 (2000), 69-77.

[25] D. V. Slavić, On inequalities for $\Gamma(x+1) / \Gamma(x+1 / 2)$, Univ. Beograd. Publ. Elektrotehn. Fak., Ser. Mat. Fiz. 498-541 (1975), 17-20.

[26] J. WALlis, Arithmetica Infinitorum, Oxford, 1656.

[27] G. N. Watson, A note on gamma function, Proc. Edinburgh Math. Soc., 2, 11 (1958/59) and Edinburgh Math. Notes 42 (1959), 7-9. 